\section{RAZGRNIMO SKRIVNOSTI DISLEKSIJE \\ Odlike in težave ljudi s posebnimi sposobnostmi}

Prof. $d r$.

Ana Krajnc, Filozofska

fakulteta Univerze

v Ljubljani

\title{
POVZETEK
}

Disleksija (diskalkulija) je posebno nevrološko stanje. Včasih je povezano z levičarstvom osebe. Pri ljudeh z disleksijo se pojavijo izpadi določenih sposobnosti in nekateri nadpovprečni talenti. Izostale sposobnosti so lahko zelo ozke, npr. sposobnost poslušanja in razumevanja tega, kar oseba sliši, sposobnost govornega izražanja, sposobnosti vizualne percepcije, sposobnost branja, sposobnost pisnega izražanja, občutek za kvantitativna razmerja (numeričnost), smisel za red, prostorska orientacija, obvladovanje zaporedij (abeceda, poštevanka, dnevi v tednu, meseci), posluh itd. Ob vstopu v šolo se pokažejo učne težave. Učenec se dolgo privaja branju, bere z okenčkom, izpušča črke, obrača črke $(s, z, b, d)$ in številke, predvsem pa grdo piše in dela veliko napak. Vidna značilnost so nižji dosežki od intelektualnih sposobnosti osebe, dokler ne razvije svojith posebnih strategij za branje, pisanje in premagovanje drugih primankljajev. Potem gre njegova pot strmo navzgor. Postane uspešen poslovnež, politik, umetnik, znanstvenik ali kaj drugega. Življenjske poti ljudi z disleksijo so navadno skrajne: ali zelo uspešne (če se dokopljejo do svojih talentov) ali pa povsem neuspešne, če podležejo učnim težavam že na začetku šolanja.

Ključne besede: disleksija, sposobnosti, talenti, učne težave

\section{KAJ JE DISLEKSIJA?}

Disleksija ali diskalkulija je nevrološko stanje človeka, je način delovanja živčevja, ki odstopa od povprečnega stanja $v$ pozitivnem in negativnem smislu. Posebno nevrološko stanje vpliva na vedenje, učenje, percepcijo in način življenja te osebe. Pogosto se takemu človeku ljudje v okolju čudijo, kako da v trenutku najde pravo rešitev, zakaj je mnogo prej pred drugimi zaslutil prave cilje podjetja, zakaj je čez noč postal slaven umetnik, zakaj je takoj prišel do pravilne rešitve matematične naloge, ne da bi sledil zaporedju postopka in potem, ko ni dolgo nič dal od sebe, itd. Človek z disleksijo preseneča ljudi $v$ okolju tudi z drugimi nenavadnimi pojavi. Ljudje postanejo nanj pozorni zaradi popolnega izpada nekaterih nevroloških in psihičnih funkcij. Taki primeri so: mož, ki je bil že znan pisatelj, a se vse življenje ni mogel naučiti abecede in je zelo težko uporabljal slovar; primer priljubljenega in zelo rázgledanega dolgoletnega ravnatelja, ki ni znal brati; branja se je naučil šele po upokojitvi skupaj s svojim vnukom; ter primer diplomantke ekonomske fakultete, ki je študij končala med prvimi, čeprav je študirala samo slušno in ni prebrala niti ene knjige ali član$\mathrm{ka}$, niti se $\mathrm{v}$ štirih letih ni naučila poti do svoje fakultete.

Posebnosti ljudi $\mathrm{z}$ disleksijo so organsko 
pogojene. Seveda jih pozneje začneta prekrivati tudi psihološka in socialna dinamika. Zato je pomembno, da disleksijo že pri

\section{Disleksijo povzroča poseben nacin delovanja živčevja.} otroku čimprej odkrijemo in s tem preprečimo mnoge negativne vplive iz okolja. Hudo je, če ne ve, zakaj se mu drugi posmehujejo ali ga na druge načine šikanirajo, ker je drugačen od večine. Pogosto mu okolje vzbuja občutke manjvrednosti in ti zadržujejo rast samozavesti. $Z$ nizko samozavestjo pa postane življenje zelo težko.

Pri osebi z disleksijo se mešajo nadpovprečne sposobnosti in popolni izpadi nekaterih sposobnosti. Zato okolje postane sumničavo do osebe $\mathrm{z}$ disleksijo, ljudje ji ne verjamejo, da je res sama kaj izračunala ali naslikala. Takšni osebi tudi ne verjamejo, da ne more brati črno napisanega teksta na beli strani, saj so praktično vse knjige tako natisnjene. Nekateri ljudje na osebo z disleksijo celo reagirajo z užaljenostjo, ker menijo, da se iz njih norčuje: nekaj zna briljantno, drugje čisto odpove.

Osebe $\mathrm{z}$ disleksijo glede na njihovo posebno nevrološko stanje čaka v življenju $\mathrm{v}$ večini
Disleksiki v sodobnih družbah predstavljajo rezervoar originalnih idej. primerov skrajna usoda: ali skrajno uspešno življenje in velik vzpon ali pa globok padec in nesrečna usoda. Kot da ne morejo hoditi po neki srednji, zmerni življenjski poti. Če ljudje niso dovolj osveščeni in razgledani ter ne poznajo pojavov disleksije, ocenjujejo človeka z disleksijo kot čudaka, lenuha, lažnivca in mu prilepijo še druge moralne etikete.

Če človek z disleksijo ne doseže dovolj hitro vidnega uspeha, s katerim si utrdi svoj družbeni položaj, je $\mathrm{v}$ nevarnosti, da ga družba stigmatizira in poriva na dno. $\mathrm{S}$ tem pa družba nehote zamori veliko talentov in zavrže potencialne genialne umetnike, izu-
Oseba z disleksijo lahko čez noč zablesti in uspe ali pa napravi tako napako, da konča v zaporu, Tuje študije kažejo, da je med zapornili 40 odstotkov oseb z disleksijo, prav tako pa je nad 40 odstotkov ljudi $z$ disleksijo med uspešnimi menedžerji. To predstavlja veliko večje povprečje, kot ga predvidevajo povprečno v populaciji in naj bi znašalo 20 do 25 odstotkov.

mitelje, znanstvenike in poslovneže. Razvita informacijska družba ali družba znanja si kaj takega ne more več privoščiti, saj sta gospodarski uspeh in socialni razvoj odvisna od ustvarjalnosti, idej, kulture (torej človeške proizvodnje) in je zato dragocen vsak talentiran človek in vsaka sposobnost, še posebej ustvarjalnost, drugačnost, enkratnost in neponovljivost sposobnosti in lastnosti človeka, kar pri ljudeh z disleksijo pogosto srečamo. Zato se $v$ sodobnih družbah posveča vedno več pozornosti ljudem z disleksijo, saj predstavljajo rezervoar originalnih idej in holističnih rešitev za probleme. Težko pa se podredijo serijam in zaporedjem. Zato se ne naučijo abecede, poštevanke, seznama imen, dnevov $v$ tednu itd. Na serialnem učenju in zaporedjih sloni šola, življenje pa ne. Č je bil nekdo slab v šoli, je lahko izredno dober in uspešen $v$ življenju. Take primere pozna vsak od nas.

$\mathrm{V}$ večini družb se vedno bolj zavedajo, kako so za preživetje vsakega človeka nujno potrebne razvite sposobnosti, osebnostne lastnosti in izobraženost. Zato se v izobraževanju odraslih vedno bolj posvečajo vsem posebnim ciljnim skupinam, ki so imele pri izobraževanju težave in njihovi člani svojih talentov niso mogli razviti in izraziti. Andragogi se trudijo, da bi se ljudje razvili vsaj kot odrasli, če se prej zaradi raznih ovir niso mogli.

Ena od teh ovir so lahko tudi posebnosti 
Raziskave ugotavljajo, da je ljudi z disleksijo 20 do 25 odstotkov. Med njimi so velike razlike glede na to, katere sposobnosti so izpadle in katere so visoko nadpovprečne. Razlike so velike tudi glede na stopnjo disleksije. Nekateri imajo velika disleksična odstopanja, drugi pa le malenkostna. Zato se del strokovnjakov bolj nagiba $\mathrm{k}$ temu, da prištevajo med ljudi $\mathrm{z}$ disleksijo le tiste $\mathrm{z}$ največjimi odstopanji, ostale z manjšimi pa ne. Ta del strokovnjakov ocenjuje, da ima disleksijo le 4 do 10 odstotkov prebivalstva.

živčevja ali drugačne organske osnove za učenje, kot jih ima večina. Večina otrok se lahko prilagodi linearnemu, serijskemu učenju pri šolskem pouku. 20 do 25 odstotkov vsake generacije pa rešuje probleme in se uči na holističen način (drugačen od šolskega, ki je linearen) ali z več vidikov naenkrat.

Tako se $v$ razvitem svetu vedno več pozornosti posveča tudi izobraževanju odraslih z disleksijo. Če ne rešimo tega problema, smo nemočni tudi pri reševanju funkcionalne nepismenosti ljudi. Med njimi je veliko odraslih z disleksijo, ker se zaradi svojih nevroloških posebnosti niso mogli nikoli učiti na šolski način in danes brez izobrazbe ne morejo preživeti.

V deželah (Anglija, Irska, Kanada, ZDA), kjer sta znanost in praksa o disleksiji najbolj razviti, so postavili oceno, da je ljudi z disleksično drugačnosljo do četrtine prebivalstva.

V Sloveniji so se na področju disleksije otrok oprijeli nižjih številk, ker menijo, da je potrebno podpreti drugačno učenje le pri učencih z največjimi odstopanji.

\section{KAKO SE UČIJO LJUDJE Z DISLEKSIJO?}

Tudi krivulja učenja pri osebah z disleksijo ni enaka večini ljudi. Ne dviga se postopoma in nato doseže plato, na katerem se učenje bolj ali manj ustavi, po uspehu učenje le malo napreduje. Pri osebah z disleksijo začetnega naglega napredovanja pri učenju skoraj ne opazimo. Navzven izgleda, kot da se učenec še ni nič naučil (in tu se začne posmeh razreda). Potem pa, ko že učitelj obupa nad njim, ker se "z mrtve točke ne premakne", nenadoma učenec presenetljivo odlično opravi nalogo. Uspehi učenja so nenadni, skokoviti, ker mora oseba z disleksijo najprej nabrati dovolj vtisov in podrobnosti, potem se vse strne $\mathrm{v}$ eno samo točko in nenadoma zna, zna bolje kot drugi, zna celostno. Do nenadnega uspeha pride, če mu damo dovolj možnosti, da dela po svoje in dovolj časa. Postopek akumulacije vtisov in podatkov lahko prezgodaj prekine učitelj misleč Ta se tako nikoli ne bo tega naučil in tako nikoli ne odkrije, kako odlično bi oseba z disleksijo lahko prav to znala, če ne bi učitelja preveč motil uvodni čas brez odzivanja učenca.

Večina stvari, ki se jih učimo v šoli in pogosto tudi doma, gre po linearni poti učenja in $\mathrm{v}$ seriji, zaporedju, pa naj bo to angleška lekcija, vožnja s kolesom ali plavanje. Naj se še tako trudimo $\mathrm{z}$ otrokom $\mathrm{z}$ disleksijo, da bi se naučil npr. voziti kolo, precej časa ne bo pokazal nobenega odziva. Kot da nas ne sliši in ne vidi. Videti bo, kot da sploh ne sledi učiteljevi razlagi in raznim poskusom učenja Ulčni uspehi disleksika so nenadni in skokoviti. po učnih korakih niti demonstraciji, kako naj npr. zažene kolo, kako naj se usede na kolo, kako naj lovi ravnotežje, kako náj se odpelje. Otrok bo trmasto odbijal vsako sodelovanje in se mu upiral. In ko boste odnehali, popustili, ker ste nad njim obupali, zato ker Sploh ne sodeluje, kako naj ga kaj naučim!, se bo otrok nenadoma elegantno odpeljal s kolesom, kot da se vozi že vsaj leto dni. Ko primerjamo učenje tega otroka $\mathrm{z}$ učenjem vožnje s kolesom pri ostalih otrocih, postopo-
AS I 


\section{Oseba z disleksijo sprejema več vtisov, kot jih zahteva postopek linearnega učenja.}

ma in po fazah mentorja, lahko ugotovimo, da se je otrok $\mathrm{z}$ disleksijo morda naučil voziti celo prej kot ostali, vsekakor pa bo že prva vožnja boljša kot po postopnem privajanju vožnji s kolesom pri ostalih otrocih.

Učitelji še vedno mislijo, da je samo postopno učenje nekaj vredno, ker imamo pri tem občutek, da nas učenci ubogajo, da nam sledijo in je vse tako, kot je prav po posameznih progresivnih didaktičnih korakih, medtem ko je učenje osebe $\mathrm{z}$ disleksijo skokovito in se učni rezultati pokažejo nenadoma in ne postopoma, kot je to običajno pri linearnem učenju. Menijo, da je šolski način dela, postopno serialno učenje po učnih korakih, edina zanesljiva in pravilna pot do znanja. (Rees, Savitzky, 2001)

\section{Učitelji zaradi} neznanja grenijo živlienje osebam z disleksijo.

Oseba z disleksijo se uči zvezdasto. Pobira vse, tudi najbolj različne in kontradiktorne informacije in vtise, zato jih sprejme več kot učenec $\mathrm{v}$ postopku linearnega učenja. V celoto jih združi in poveže šele na koncu in takrat nenadoma zna. Če učitelj ne prisega na serialno učenje in postopnost učnih korakov, bi se mu zdelo, kot da verjame v čudeže. Da, in prav pri disleksičnih otrocih se pojavljajo pri učenju "čudeži", nenadni preskoki v novo znanje. Tako prepričanje je v razkoraku z osnovnimi

\section{Einstein je kljub disleksiji postal} znanstvenik. lastnostmi ljudi z disleksijo. Če hočejo mentorji pomagati priti do znanja ljudem $\mathrm{z}$ disleksijo, morajo sprejeti drugo formulo: kako se ti ljudje učijo na poseben način. Tudi način učenja ljudi z disleksijo je pravilen in skladen z delovanjem možganov, ki pri njih malo drugače delujejo kot pri ostalih ljudeh. $\mathrm{Ni}$ pomembna pot do znanja, pomemben je rezultat: kaj in koliko kdo zna. (Literacy and Numeracy, 2000)

\section{PRAVILEN REZULTAT BREZ "PRAVILNEGA" POSTOPKA}

Učenje ljudi $\mathrm{z}$ disleksijo ima tudi mnoge prednosti pred linearnim učenjem. Nekaj jih lahko osvetli naslednji primer. Dijaki srednje šole pišejo kontrolko. Prvi pride do točnega rezultata in dvigne glavo dijak v kotu. Profesor stopi k njemu: "Kje je postopek? Kako si prišel do rezultata? Zakaj nisi napisal celotnega postopka?" in že ga sumljivo gleda. Dijak molči, malo je zbegan, še samemu mu ni povsem jasno, kako je tako hitro odkril rešitev matematične naloge in povsem pravi rezultat. Zato molči, nič ne reče, celo malo ga je sram, kot da je napravil nekaj narobe. Pri profesorju pa se dviga nejevolja: "Prepisal si od koga. Ker nisi napisal postopka, ti bom ocenil negativno ..." Dijak se počuti ponižanega, trpi in molči. "Kako bom od drugih prepisal, če sem prvi končal?" si misli sam pri sebe, a molči. V srečo se mu je zapisala še ena slaba izkušnja $v$ šoli.

"Zakaj mu učitelj ne verjame, zakaj ga pred razredom obsoja za nekaj, česar ni napravil?" Tudi ta vprašanja ostanejo le nema v njem, saj še sam ne ve, kaj je z njim narobe. Tudi če prav izračuna, mu učitelj tega ne prizna. Še nihče ni odkril, da ima fant disleksijo in računa na drugačen, holistični način. Podrobnosti postopka pri računanju se ne zaveda, misli letijo križem kražem in hitro. Naenkrat se mu posveti rezultat in ga zapiše. Ko nam kdo od ljudi z disleksijo (diskalkulijo) poskuša vsaj delno opisati, kako je računal, doživimo to kot nekaj povsem nenavadnega. (Yoshimoto, 2002)

Ljudje z disleksijo pretrpijo veliko ponižanj, ker grdo pišejo. Grda pisava je eden od značilnih znakov disleksije. Tudi Einstein je grdo pisal in je bil disleksik, kljub temu pa je 
postal eden največjih znanstvenikov človeštva. Na otroke $z$ grdo pisavo se začno jeziti že učitelji ob vstopu v šolo. Grdo pisavo povezujejo $\mathrm{z}$ nemarnostjo in lenobo otroka, zadeva dobi moralno obeležje in tak odnos ga zaznamuje za vse življenje. Pisava je izrazito nevrološka zadeva, $Z$ voljo se da le malo spremeniti, tudi npr. smisel za red. Dokler se nevrološko stanje ne spremeni, se tudi pisava ne bo izboljšala. Včasih se to zgodi po operaciji možganov. Učitelji bi morali sprejeti pisavo kot objektivno dejstvo in ne otroka zaradi nje kritizirati. Saj tudi ne kritiziramo učenca, ki ima modre oči in mu ne očitamo, zakaj nima črnih. Zaradi grde pisave se tak človek izogiba, da bi karkoli pisal tudi kot odrasel, ker meni, da tega ne zna, "da on za to ni in nikoli ni bil dober". Začne se podcenjevati še na drugih $s$ pisavo povezanih področjih ali dobi celo manjvrednostni kompleks. Ko mu diagnostik kdaj pozneje $\mathrm{v}$ življenju pove, da bi lahko glede na svoje nekatere nadpovprečne sposobnosti in osebne lastnosti bil pisatelj, mu ne verjame in takoj zavrže misel na to.

Čustvene travme in izgube osebe $\mathrm{z}$ disleksijo so lahko zelo velike. Če ljudje v okolju ne razumejo drugih $\mathrm{z}$ disleksijo in jim ne priznavajo pravice, da se učijo na svoj način, jih lahko zaradi čustvenih izgub in kompleksa manjvrednosti porinejo $\mathrm{v}$ destruktivno Živ- ljenje, kriminal in zapor, čeprav bi lahko isti bili umetniki, znanstveniki, uspešni poslovneži. (Parsons, 2002/1)

Navedli smo le nekaj primerov nesporazumov in težav zaradi odstopanja od glavnega toka (main stream) učenja. Literatura jih našteva še mnogo več. Pri odraslih z disleksijo se problemi s področja učenja razširijo na področje dela in načina odločanja v življenju.

\section{KDAJ SO ODKRILI DISLEKSIJO?}

V Sloveniji je bila bolj poznana kot legastenija. Izraz smo prevzeli iz nemškega jezika. Ker je angleška literatura bolj pogosta in so $\mathrm{v}$ ZDA, Kanadi, Angliji in na Irskem tudi najbolj razvili znanost in prakso na tem področju, se je $v$ zadnjih desetletjih vedno bolj uveljavljal angleški izraz za isti pojav: disleksija (dyslexia). Tako se imenuje tudi Evropsko združenje za disleksijo in večina nacionalnih društev, zato tudi $v$ Disleksiki zaradi nerazumevanja
okolja trpijo za-
radi pomanjkanja
samozavesti. Sloveniji uporabljamo izraz disleksija kot sopomenko legasteniji. Izraz izhaja iz dveh starogrških besed: "dys", kar pomeni težava, in "lexikos", kar pomeni beseda. Izraz sam torej označuje predvsem "težave $\mathrm{z}$ besedami", bodisi da jih vidimo, pišemo, slišimo ali
Izraz disleksija pomensko pokriva, če bi ga dosledno razlagali, le pojave govora in branja pri neki osebi in ne vseh pojavov, povezanih z nevrološkimi učnimi posebnostmi, kot je npr. sposobnost za določanje količinskih razmerij (diskalkulija), razlike $\mathrm{v}$ uspešnosti namenskega in nenamenskega uěenja, sposobnost miselne koncentracije, prostorska orientacija, posebni pojavi sociabilnosti (Tesla je vse življenje živel sam, prijatelj mu je bil golob, svoje iznajdbe ni uveljavljal v javnosti, zato pa je imel toliko bolj genialne zamisli od ostalih). Pri učnih težavah ločijo strokovnjaki tudi dispraksijo ali težave na področju predelave senzornih informacij, načrtovanja, in izvajanja namenskih gibov. Pri šolskih otrocih se včasih izraža v težavah pri risanju (te so mnogo pod intelektualnim nivojem učenca) in pri prostorski orientaciji. Tako kot druge nevrološko pogojene težave tudi dispraksija ne izzveni v otroštvu, oseba vse življenje živi s tem primanjkljajem, ki vpliva na šolanje, zaposlitev in življenje nasploh. 
Osebe z disleksijo so prisiljene razviti obrambne strategije.

izgovorimo. Pod disleksijo kot neyrološko disfunkcijo pa danes obravnavamo mnogo širše pojave pri človeku. (Krupska in Klein, 1995, str. 5-15) Najbolj se je uveljavil izraz disleksija, zato ga bomo iz praktičnih razlogov uporabljali širše in pri tem vključevali tudi diskalkulijo in dispraksijo. Pri diagnosticiranju strokovnjaki odkrivajo, da so učne težave mešane in se poleg disleksije pojavljata tudi diskalkulija in dispraksija, pri vsaki osebi na drugačen način. Zato pri vsaki osebi z disleksijo individualno pristopamo pri diagnozi, svetovanju, zaposlovanju in drugih odločitvah. (Kavkler, 2002, str. 173-176; Pulec Lah, 2002, str. 193-195)

Disleksijo so začeli odkrivati šele v začetku dvajsetega stoletja, ko so bili šolski sistemi in šolske mreže dovolj razvite, da so zajele v šolsko obveznost praktično vse otroke.

V Sloveniji so poskušali dati pojavu nek širši pomen in govorijo o "učnih težavah" ali "primanjkljajih na posameznih področjih učenja" (PPPU) (Magajna, Kavkler, 2002, str. 3-7). V

Proaktiven pristop $k$ disleksiji je odkrivanje posebnih sposobnosti. javnosti in tudi $v$ prizadetih družinah menijo, da je legastenija ali disleksija predvsem učna težava, manj pa razmišljajo o talentih tega otroka, njegovih prednostih. Če bi preveč poudarjali samo izpade $v$ sposobnostih in težave, bi bilo nevarno, da se o disleksiji ustvari preveč enostranska podoba samo težavnosti v stanju osebe. Celovitejšo podobo o disleksiji dobimo, če poudarimo tudi posebne talente (npr. krasno pleše balet, težko bere in piše z mnogo napakami) in visoke sposobnosti, značilne za osebo. S poudarjanjem težav in zamolěanjem talentov so otroci $\mathrm{z}$ učnimi težavami stigmatizirani in ravno tako odrasli. Zato to skrivajo. Odrasli razvijejo cele strategije, da svoje težave prikrijejo. Podobno ra- vnajo tudi funkcionalno nepismeni ljudje, pri njih je vzrok težav psihološki, ekonomski in socialni. Npr. dekle nestrpno čaka pismo svojega fanta, ta ji ne piše, ker dela preveč napak, zato se ji izgovarja, da je pošta nezanesljiva in se pisma izgubljajo. Vsak rešuje svoj socialni status na drugačen način. Obrambne strategije so zelo domiselne in koristne (Kavkler, ur, 2002).

Razumljivo je, da se najprej lotimo disleksičnih težav pri otroku ali odraslem, ker so najbolj moteče, Drugi korak pri obravnavanju oseb z disleksijo pa je odkrivanje talentov in prednosti, ki jih ima njegov način percepcije in reagiranja na zunanji svet. Tu lahko veliko pomagamo s poklicnim svetovanjem. Napačna poklicna odločitev in zanemarjanje dejanskih talentov spremeni življenje $v$ pravo muko. Pred kratkim smo se pogovarjali z gospo, ki je vse do upokojitve delala kot računovodja, njene glavne disleksične težave pa so bile obračanje številk in nezmožnost percepcije ali reprodukcije serije, zaporedja. $\mathrm{V}$ kakšnem strahu in napetosti živiš, če nisi prepričan, ali piš̌e 13 ali 31 milijonov! Poklicno delo se spremeni $v$ trpljenje, talenti pa ostanejo za vedno neodkriti.

Disleksična oseba $\mathrm{s}$ težavami govora in poslušanja je navadno zelo sposobna za holistično grafično izražanje: $\mathrm{z}$ eno risbo izrazi toliko, kot bi nekdo, ki je verbalno nadarjen, povedal $\vee$ dolgem govoru ali opisal $\vee$ razpravi. Če je risanje glavna pot izražanja, se oseba $\mathrm{z}$ disleksijo mora naučiti risarske tehnike in s tem odpre "svoj glavni kanal komuniciranja". Odkrivanje talentov je enako pomembno kot ugotavljanje izpadlih sposobnosti.

\section{KDAJ SO V JAVNOSTI POSTALI POZORNI NA DISLEKSIJO ODRASLIH?}

Že prej smo rekli, da so disleksijo otrok odkrili na začetku dvajsetega stoletja, ko so v šolanje zajeli vso rojeno generacijo in je 
postalo očitno, da del otrok ne prenese linearnega serialnega učenja. Tako so razvite družbe $v$ sedemdesetih letih prejšnjega stoletja (od 1970. dalje) postale pozorne na funkcionalnó nepismenost dela prebivalstva, zlasti masovno zaposlenih ljudi na najnižjih delovnih mestih v industriji (Parsons, Binner, 2002).

Če se ljudje ne morejo (več ali še) uspešno sporazumevati z okoljem, pravimo, da so funkcionalno nepismeni. To se pri nas zgodi ljudem, ki pri šolanju niso dosegli ravni štiriletne solidne srednje šole. Seveda gre družbeni razvoj svojo pot in se s tem meja med funkcionalno pismenimi in funkcionalno nepismenimi dviga. Na Danskem je funkcionalno pismen, tj. da se $v$ svojem okolju in pogojih tamkajšnjega življenja znajde in uspešno rešuje svoje probleme, šele človek z višjo izobrazbo. Na ravni dokončane višje šole je kriterij pismenosti tudi $v$ ostalih najbolj razvitih državah. (Krajnc, 1994)

\section{PROJEKT EVROPSKE UNIJE O DISLEKSIII ODRASLIH "FORWARD"}

V Evropski uniji, v okviru projektov Grundwig 4 , že dve leti poteka projekt FORWARD ali disleksija odraslih (od leta 2002 do oktobra 2004) in se bo nadaljeval v drugi fazi še naslednji dve leti. V projektu poleg Slovenije (koordinator za Slovenijo je avtorica tega članka) sodelujejo še Norveška, Danska, Nemčija, Anglija, Irska, Ciper, Malta, Latvija, Estonija in Romunija. Koordinatorica projekta FORWARD je Norveška (prof. dr. Kari Letrud).

$\mathrm{V}$ mednarodnem timu sodelujejo strokovnjaki za izobraževanje odraslih in disleksijo. Iz Slovenije poleg avtorice članka v mednarodnem timu sodeluje še doc. dr. Dušana Findeisen. Člani tima se srečujejo na konferencah vsaka dva in pol meseca v eni od sodelujočih držav. Poročajo o opravljenih nalogah po zadnji konferenci, načrtujejo naloge tima do naslednje konference in ocenijo stanje $\mathrm{v}$ pra-

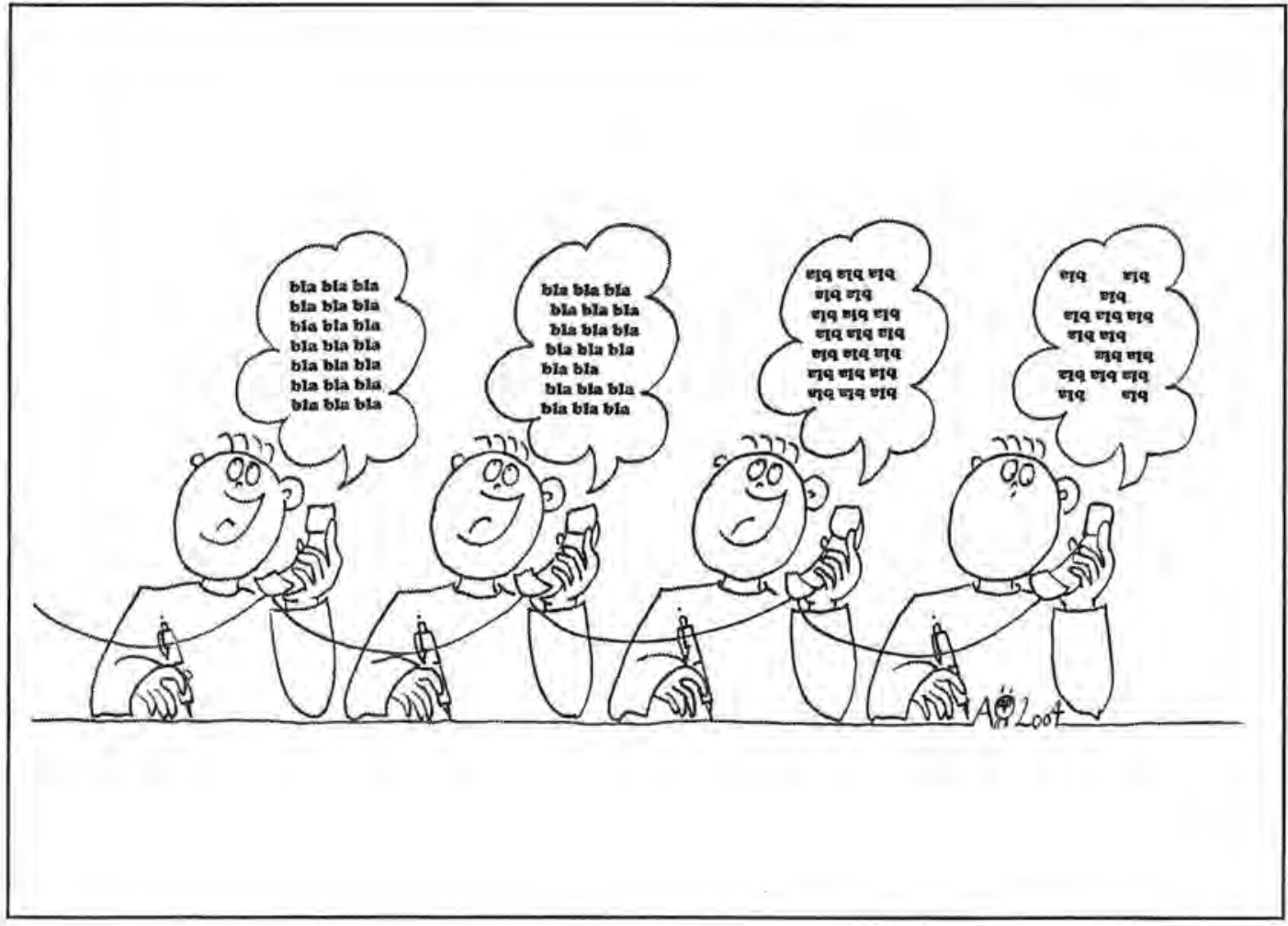


ksi in teoriji na področju disleksije odraslih v državi, kjer je srečanje.

Konec maja letos bo konferenca mednarodnega FORWARD tima v Ljubljani. Organizira in vodi jo Univerza za tretje življenjsko obdobje. Mednarodni tim se bo takrat srečal z ministrom za šolstvo, znanost

\section{Disleksijo je moč ugotoviti ali potrditis testiranjem.}

in šport in strokovnjaki s sektorja za razvoj in sektorja za izobraževanje odraslih istega ministrstva, s strokovnjaki Svetovalnega centra za otroke in mladostnike, $\mathrm{s}$ sodelavci Andragoškega centra Slovenije in s sodelavci Oddelka za pedagogiko in andragogiko Filozofske fakultete Univerze v Ljubljani.

Pred konferenco, 27. maja, bo na Filozofski fakulteti poldnevni seminar o disleksiji odraslih za vse zainteresirane, ki delajo ali odločajo na področju izobraževanja odraslih. Vodila ga bo ena najbolj znanih evropskih strokovnjakinj za disleksijo odraslih Angležinja prof. dr. Helen Suntherland. V delavnici in odprtem forumu bodo lahko udeleženci diskutirali o pojavih disleksije odraslih, ki jih pri nas šele odkrivamo, o tem, kako se izrazijo posebni talenti in kako disleksijo odkrivamo.

Pričevanja nekaterih odraslih ljudi $\mathrm{z}$ disleksijo v Angliji povedo, da se zasmehovanja sošolcev ne otresejo vse življenje. Vedno ga imajo pred očmi kot najhujšo travmo in ponižanje ter si ne morejo izboljšati nizke ravni samozavesti. Tudi če so imeli kot odrasli velike in vidne uspehe kot umetniki ali poslovneži, jih še vedno pritiskajo $\mathrm{k}$ tlom negativne izkušnje iz šole. Veliko jim pomeni že to, da jim nekdo postavi diagnozo in pove, da imajo disleksijo, pa čeprav se to zgodi šele pri štiridesetem ali petdesetem letu starosti. Slišali smo izjave: "Sedaj vsaj vem, da nisem neumen, sedaj vem, da imam disleksijo in kaj je to. Laže mi bo pri duši. Prej sem se počutil krivega tudi za svoje uspehe zaradi prepričanja, da sem neumen, ki so mi ga vcepili že v šoli. Diagnoza, ki ste mi jo povedali, me razbremenjuje občutkov krivde. Mojemu delu bo dala še večji polet. Sedaj vsaj vem, kaj sem ..." (Krupska, Klein, 1995)
V okviru projekta FORWARD smo dobili na razpolago teste in preizkuse za ugotavljanje disleksije odraslih. Vendar večine preizkusov ni mogoče uporabljati enostavno prevedene. Po analogiji lahko odkrivamo in razvijamo naše domače preizkuse za disleksijo, ki so prilagojeni našemu jeziku, kulturi ter socialnemu in psihološkemu pomenu posameznih značilnosti in pojavov. Ali kot pravijo $v$ angleščini: "Not translation, but invention." (ne prevod, ampak iznajdba).

$\mathrm{V}$ angleščini je črkovanje besed zelo poudarjeno in način pisanja se zelo loči od izgovorjave. V angleških šolah se otroci pravilnega pisanja besed učijo štiri leta. Prav tu imajo otroci in odrasli z disleksijo velike težave, Slovenščina kot jezik ni tako zahtevna pri pisanju kot angleščina, zato bodo težave ljudi $\mathrm{z}$ disleksijo pri nas drugačne. (Parsons, 2002/2)

Na Danskem sta obveljali dve teoriji o ugotavljanju in razvijanju talentov ljudi z disleksijo. Ena in druga sta globoko zasidrani v danskem jeziku in danski kulturi. Ker obe teoriji upoštevata bistvene značilnosti, sta enako uspešni pri ugotavljanju in obravnavanju disleksije. Veliko pomagata pri odpravljanju funkcionalne nepismenosti prebivalstva. Razvili so simpatične računalniške programe, zelo enostavne za uporabo z dotikom, kjer lahko vsak človek zase odkriva in razvija svoje talente. Čeprav so ga nekoč v šoli imeli za najslabšega učenca $v$ razredu in so se mu vsi smejali, ker je npr. izpuščal črke $v$ besedah ali ni zagledal grafikona, čeprav ga je ves razred videl, ker je govoril o neverjetnih in nesmiselno velikih količinah itd., pa danes odkriva, da je za marsikaj, česar se prej ni zavedal, sposoben, in mu končno tudi samozavest raste. Danski strokovnjaki za izobraževanje odraslih in disleksijo zelo podpirajo razvoj samozavesti in sposobnosti ljudi s slabimi šolskimi izkušnjami.

Ker je živčevje zelo zapleteno in pri vsakem 
človeku nekoliko drugačno, je disleksija zelo razpršen pojav. Pri vsakem človeku z disleksijo se pokaže nekoliko drugače. Kot pojav ima le nekatere skupne značilnosti, ki pa se prav tako ne pojavljajo pri vseh ljudeh $\mathrm{z}$ disleksijo, npr. levičarstvo, grda pisava, nespretne roke, izpuščanje črk, zelo zgodnji pojav govora (pri 10 mesecih) ali pa zelo pozen pojav govora (pri dveh letih in pol starosti), nenavadno miselno vzorčenje, nadpovprečno abstraktno mišljenje, visoko razvita intuicija, hólistično reševanje problemov, sposobnost za nenavadne podrobnosti $\mathrm{v}$ vizualni ali slušni percepciji okolja itd.

Na Norveškem in v Angliji so bili ljudje presenečeni, ko so začeli tekst gladko brati, če je bil pokrit z barvastimi temno rdečimi ali temno modrimi prosojnicami. Prvič v življenju so kot odrasli s pomočjo strokovnjaka odkrili, da niso neumni, ampak zaradi nevroloških pogojev (živčevja) drugače percepirajo svetlobo, Zaznavajo le del svetlobnega spektra, drugega pa ne. To seveda s pametjo, kot pravimo, ali inteligenco nima nič skupnega. Po postavljeni diagnozi so jim preprosti barvni pripomočki (posebna barvna očala ali barvne folije za prekrivanje teksta) omogočili, da gladko berejo. Kakšno veliko živjjenjsko presenečenje. Kot da so začeli živeti novo življenje! (Ireland, 1991)

Evropska skupnost si prizadeva, da bi približali stopnjo razvitosti vseh držav članic tudi na področju obravnavanja disleksije s tem, da bi dosežke znanosti in pozitivne primere iz prakse razširili iz ene države $v$ druge. V tem je globok smisel mednarodnega sodelovanja, sicer bi vsak posebej odkrivali isto stvar.

\section{KDO MORA POZNATI DISLEKSIJO?}

Disleksija se ne dotakne samo osebe, ki to nevrološko stanje ima, ampak tudi ostalih ljudi v okolici. Starši bodo bolje razumeli svojega otroka in mu laže pomagali, če bodo čimprej spoznali, da ima otrok disleksijo in bodo $\mathrm{z}$ njim drugače ravnali. Bratje in sestre bodo manj prizadeti zaradi vedenja njihovega brata ali sestre, če bodo razumeli, zakaj se obnaša tako. Družina je prva, ki spodbuja talente otroka $\mathrm{z}$ disleksijo in ga brani pred negativnimi psihosocialnimi vplivi okolja. Starši

Družina in učitelji
morajo prvi biti
seznanjeni z
disleksijo.
spremljajo svojega otroka tudi v vrtcu. Vzgojiteljici lahko veliko povedo o njem. Tako mu lahko da igre, kjer bo uspešen, in razloži potrebno o disleksiji tudi ostalim otrokom $\mathrm{v}$ vzgojni skupini.

Glavne težave se pokažejo $v$ šoli. Še vedno ugotavljamo, zlasti v šolah izven Ljubljane, kamor Svetovalni center za otroke, mladostnike in starše ne doseže, da učitelji praktično nič ali pa zelo malo vedo o disleksiji. Čeprav odkrivajo, da dosežki otroka niso v skladu z zaznavno intelektualno ravnijo otroka, ampak mnogo nižji, ga pošljejo na kategorizacijo ali pa so užaljeni, ker se pri nekaterih šolskih predmetih odlično izkaže, drugje pa je njegov uspeh zelo slab in ga učitelj povezuje $\mathrm{z}$ lenobo, pomanjkanjem volje itd. Veliko napačnih ocen in slabih občutkov bi prihranili v šoli, če bi vsak učitelj šel skozi program dopolnilnega izobraževanja o disleksiji. To bi bilo tudi uresničljivo $\mathrm{v}$ okviru programov Permanentnega izobraževanja učiteljev. Najprej bi morali načrtno pripraviti skupine "multiplikatorjev", za disleksijo specializiranih predavateljev. Ministrstvo za šolstvo, znanost in šport pa bi moralo sprejeti politično odločitev o strateškem načrtu, kako bodo postopoma $\mathrm{v}$ to dopolnilno izobraževanje vključevali vse učitelje. Morda bi najprej začeli z najmlajšimi, z učitelji z enim do pet let prakse, in tako naprej postopoma vse do najstarejših učiteljev. Za multiplikatorje dopolnilnega izobraževanja za učitelje o disleksiji bi lahko usposabljali že upokojene 
učitelje, ki bi se po svoji dolgi praksi v šoli posebej specializirali in posvetili problemom disleksije. Tak pristop bi veliko pripomogel $\mathrm{k}$ izboljšanju prakse pri delu z otroki z učnimi težavami. Na tak način rešujejo probleme disleksije v Nemčiji. Upoko$\checkmark$ Kanadi in Angliji so s finančnimi instrumenti zaščitili pravice oseb z disleksijo. "patronažno izobraževanje" in mentorstvo na domu za otroke $\mathrm{z}$ disleksijo. $\mathrm{V}$ njihovi praksi se je to zelo obneslo. Morda bi tudi naše upokojene učitelje zamikalo, da bi igrali jeni učitelji izvajajo tudi $v$ družbi spet aktivnejšo vlogo in bi spet dobili občutek, da tudi sami napredujejo. Izkušnja bi bila zelo nagrajujoča za obe strani.

V Kanadi država ne financira letnika visokošolskega študija, če s podatki ne dokažejo, da imajo v letniku vsaj 10 odstotkov študentov z disleksijo. Tako je država poskušala preprečiti nepotrebno izgubo velikih talentov in zaščititi osebe z disleksijo. Študentje imajo pravico, da namesto teksta dobijo ustno razlago, in obratno, odvisno od tega, katera pot percepcije jim bolj ustreza. Izbirajo lahko tudi način preverjanja znanja. Nekateri so uspešnejši pri pisanju, drugi pri govoru. V Angliji dobi vsak registriran študent $\mathrm{z}$ dislek- sijo tudi individualnega mentorja. Ta mu še posebej pomaga prebujati osebne talente in premagovati študijske težave. Za mentorje je zelo pomembno, da študente poznajo tudi s strani drugih življenjskih situacij in ne samo študija. Vsak študent z disleksijo je svet zase. Več je razlogov za to, da je, kot pripovedujejo profesorji, mentorstvo naporno, vendar finančno primerno nagrajeno (McCarthy, 2003).

Seveda je tako zelo pomembno, da ima študent zares strokovno potrjeno diagnozo disleksije (diskalkulije ali tudi dispraksije). V ta namen ustanavljajo vedno več diagnostično-svetovalnih centrov za disleksijo. V Angliji in Kanadi so pregledi brezplačni (financira jih država), če osebo napoti v diagnostični center npr. služba $\mathrm{z}$ univerze, kadrovska služba delovne organizacije, center za socialno delo, zdravstveni dom, sodišče, razna društva, ali kakšna druga organizacija, ki želi tudi uradno potrdilo o tem, da oseba zares ima disleksijo. Število diagnostično-svetovalnih centrov za disleksijo narašča tudi na Danskem. Če diagnostično-svetovalna služba potrdi, da ima oseba disleksijo, potem država financira nakup računalnikov, posebnih računalniških programov za ljudi $s$ te-

Znanje o disleksiji je eno temeljnih znanj o ljudeh tudi za strokovnjake v kadrovskih službah. Dekan fakultete za družbene vede in humanistiko univerze Linkoping na Švedskem je na mednarodni konferenci v Zagrebu (Pučko sveučilište Zagreb, 1989) pojasnil, kako obupno je bilo stanje z njegovo tajnico prvi dve leti. Večkrat je zahteval, naj jo kadrovska služba Univerze odpusti. Ti pa so jo zagovarjali in jo še naprej zadrževali na istem delovnem mestu. Včasih se mu je situacija zdela obupna, še posebej zato, ker je sam zelo pazil, da ni delal napak in je bilo vse pravočasno. Večino stvari je tajnica napravila narobe, jih potem popravljala in spet so bile napake drugje. Napake so se lahko nepričakovano kjerkoli pojavljale. Izgledalo je, kot da se ne more ničemur prilagoditi in nič več, kljub mladosti, naučiti. Njegov odnos do tajnice je nihal med užaljenostjo in ogorčenostjo. In ko je že sam razmišljal, da bi odšel kam drugam v službo, se je tajnici nenadoma odprlo in postala je tajnica brez primerjave. Seveda je pozneje odšel dekan drugam v službo, vendar je tajnico vzel s seboj, ker se mu je zdelo, da ji ni para. 
Žavami pisanja, poslušanja in branja ter še druge oblike podpore.

Kadrovska služba in vodilni so vmesni člen med osebo z disleksijo in sodelavci. Če pravilno uravnavajo odnose in položaj delavca z disleksijo, bodo omogočili, da se čimbolje izkoristijo njegovi talenti in preskočijo izpadi sposobnosti. Zato je potrebno, da imajo dovolj znanja o disleksiji tudi $v$ delovnih organizacijah, še posebej strokovnjaki v kadrovskih službah in vodilni.

Znanja o disleksiji bodo podpirala tudi reševanje problemov funkcionalne pismenosti, ki je največji problem med brezposelnimi. S funkcionalno nepismenostjo se ukvarjajo vse ustanove za izobraževanje odraslih, zavodi za zaposlovanje, centri za socialno delo in delovne organizacije. Znanja o disleksiji potrebujejo tudi $v$ pravosodju in upravnih službah, povsod, kjer imajo opraviti z ljudmi. Drugače bodo napačno in neuspešno reševali probleme, nastale zaradi disleksije.

Funkcionalno nepismeni imajo podobne težave kot osebe $z$ disleksijo, ki se niso uspele prebiti do svojih talentov in sposobnosti. Vendar je funkcionalno nepismenih $\mathrm{v}$ populaciji mnogo več kot disleksikov. Po rezultatih mednarodne študije o funkcionalni pismenosti Andragoškega centra Slovenije (zaključila se je leta 2000) je v Sloveniji 71 odstotkov ljudi funkcionalno nepismenih na področju verbalnosti in 70 odstotkov na področju numeričnosti. Določen delež med njimi predstavljajo osebe z disleksijo. Če ne rešimo problemov disleksije, tudi ne moremo biti uspešni pri reševanju funkcionalne nepismenosti pri nas. Vzroki funkcionalne nepismenosti pa so mnogo širši: socialne razmere, ekonomsko stanje, vrsta zaposlitve, razvitost okolja, kjer ljudje živijo, življenjske navade, družinska pismenost itd. (Magajna, Kavkler, Križaj-Ortar, 2003)

Znanja o disleksiji bi lahko postala del splošne izobrazbe vsakega človeka. Če tega znanja ne bi potreboval zase, bi ga lahko uporabil za medsebojno pomoč, starševstvo, v prijateljskih zvezah in za boljše razumevanje sveta in okolja, Znanje o disleksiji mora postati del splošne izobrazbe liudi. pa tudi sebe.

\section{LITERATURA}

Krupska, M., Klein, C. (1995), Demystifying dyslexia, Raising Awareness and Developing Support for Dyslexic Young People and Adults. London Language and Literacy Unit, LLLU; London.

Rees, S., Savitzky, F., (2001). Helping my child with reading and writing. South Bank University, London.

Podpora učiteljem pri đelu z učenci s specifiěnimi učnimi težavami šrom po svetu. Društvo Bravo, Ljubljana,

Literacy and Numeracy, What Aduits can and can not do? (2000). The Basic Skills Agency, London.

Parsons, S., Bynner, J, (2002). Basic Skills and Social Exclusion. The Basic Skills Agency, London.

Pulec, S. (2002). Oblikovanje in uvajanje individualiziranih programov. V Specifiěne učne težave otrok in mladostnikov. Svetovalni center za otroke, mladostnike in starše, Ljubljana, str. 193-216.

Goršič Končnik, N., Kavkler, M., (2002). Specifične učne težave otrok in mladostnikov. Svetovalni center za otroke, mladostnike in starše, Ljubljana.

Magajna, L., Kavkler, M. (2002). Primanjkljaji na posameznih področjih učenja (PPPU), V Razvijanje potencialov otrok in mladostnikov s specifiěnimi učnimi težavami. Prva slovenska konferenca o specifičnih uěnih težavah $\mathrm{z}$ mednarodno udeležbo, Svetovalni center za otroke, mladostnike in starše Ljubljana, Društvo Bravo, Different d. o. o., Trzin, str. 3-7.

Kavkler, M. (ur.) (2002). Razvijanje potencialov otrok in mladostnikov s posebnimi uěnimi težavami. Different d. o. o., Trzin.

Galeša, M. (2002). Individualiziran učni načrt in individualizirani programi. V Razvijanje potencialov otrok in mladostnikov s specifičnimi učnimi težavami. Different d, o, o., Trzin, str. 83-89.

Magajna, L. (2002). Specifične učne težave-prepoznavanje, razumevanje, premagovanje. V Specifične učne težave otrok in mladostnikov. Svetovalni center za otroke, mladostnike in starše, Ljubljana, str. 15-29.

Krajnc, A. (1994). Psihosocialni vidiki, pojav in analiza 
funkcionalne nepismenosti. Projekt: Funkcionalna pismenost - usposabljanje za življenjsko uspešnost, Andragoški center Slovenije, Ljubljana.

Are dyslexia and Wealth linked? Study finds individuals with dyslexia more likely to be millionaires (2003). Online Summaries of Important National News on Education, www.ldonline.org $<$ article.php? $\max =20 \& i d=159$ $\& \mid O C=48$

Freeman, J. R. (2004). A Game and Strengths and Weaknesses Athletics and Academics, Celebrating Strengths and Talents of People with Learning Disabilities. On-line, www.ldonline.org/arcticle.php?id $=675$ loc $=76$

Lenz, K., Schumaker, J. (2004). Adapting Language Arts, Social Studies, and Science Materials for the Inclusive Classroom. The paradox of children who are gifted and learning disabled. On-line, www.ldonline. org/article.php?id=715\&loc $=24$

West, T. G. (2004). The Abilities of Those with Reading Disabilities: Focusing on the Talents of People with Dyslexia. On-line, www.ldonline,org/article.php?id= $699 \& 10 c=76$

Yoshimoto, R. (2000), Celebrating Strengths and Talents of Dyslexic Children: An Educational Model, Celebrating Strengths and Talents of People with Learning disabilities. Operspectives, Spring 2000 - Vol. 26, No 2, The International Dyslexia Association.

Krajnc, A. (2004). Disleksija - gospostvo in prekletstvo. Delo, Priloga Znanost, 8. 3. 2004, Ljubljana.

McCarthy, C. (2003). Supporting Students with Dyslexia. A Guide for Institutions of Further and Higher Educazion. AHEAD Education Press, Dublin.

Parsons, S. (2002). Basic Skills and Crime. The Basic Skills Agency, London.

Reid, G. (2002). Nekaj v prijateljsko pomoč. Vodnik za starše otrok z disleksijo. Bravo, Ljubljana.

Parsons, S. (2002). Do I want to improve my reading, writing and math? The Basic Skills Agency, London.

Irlen, H. (1991). Reading by Colours, Overcoming Dyslexia and other reading disabilities through the Irlen method. Avery Publishing Group Inc. New York.

Magajna, L., Kavkler, M., Križaj-Ortar, M. (2003). Adults with Self-Reported Learning Disabilities in Slovenia. V Dyslexia, str. 229-251, John Wiley \& Sons Ltd., London. 